\title{
Asbestosis occurring after brief inhalational exposure: usefulness of bronchoalveolar lavage in diagnosis
}

\author{
R G BARBERS,' J L ABRAHAM ${ }^{2}$
}

From the Department of Medicine,' UCLA School of Medicine, Los Angeles, California, and Department of Pathology, ${ }^{2}$ SUNY Health Science Center at Syracuse, New York, USA

ABSTRACT A case of clinically and radiologically typical asbestosis manifesting in a 55 year old ma occurred 36 years after a brief exposure period of less than one year. A transbronchial lung biopsy waß performed but the samples were considered non-diagnostic. The diagnosis was supported by the use of bronchoalveolar lavage to obtain alveolar samples and scanning electron microscopy-energit dispersive $x$ ray analysis of fibres found in the bronchoalveolar lavage fluid which showed : predominance of amosite.

Asbestosis is usually associated with chronic inhalational exposure and occurs after a long latent period. ${ }^{1}$ The finding of asbestos bodies and fibres in the lung indicates exposure to asbestos dust. ${ }^{23}$ The present case illustrates the occurrence of asbestosis in a patient who had had brief and limited exposure to asbestos material many years before the development of symptoms and objective findings. Fibreoptic bronchoscopy with transbronchial biopsy and bronchoalveolar lavage (BAL) established the presence of asbestos bodies which confirmed the exposure and aided the diagnosis.

\section{Case report}

A 55 year old oil company executive was evaluated in 1986 because of a productive cough. He never smoked cigarettes. He had known exposure to asbestos for one year or less in 1949 and 1950 (about six months each year). At that time he worked as a chemical engineer trainee ("co-op") for a company that manufactured pipe insulation containing asbestos. He worked in an office building away from the factory site and was not aware of any exposure to asbestos dust and rarely went to the factory site. When he visited the factory he did recall being exposed occasionally to asbestos dust and he never wore a protective mask. He was in the Army Chemical Corps from 1954 to 1956 but was not aware of any exposure to asbestos then. In his current occupation as a chemical engineer for a refinery he had no known exposure to any asbestos material and

Accepted 18 January 1988 primarily did "executive" work in an office buildin雨 Although there was demolition or remodelling periodically of rooms and offices in the building, rarely visited these areas. There was no other sig. nificant occupational and environmental exposute history.

A physical examination showed bibasilar inspro tory "Velcro" type crackles that were more audibif of the left side. Recent chest radiographs were characte ised by a " $B$ " reader as bilateral small parenchym opacities (UICC/ILO classification, ${ }^{4} 1 / 1$ ), diffus pleural thickening on the right chest wall, pleurat plaques on the left chest wall, and pleural calcification above the right diaphragm (fig 1). A chest CT scan was not carried out. Previous outside chest radiograp obtained in 1970 (fig 2), 1977, 1979, and 1982 showed progression of abnormalities; chest films before 1970 were not available. Recent pulmonary function testing results are presented in the table. The forced expiratory volume in one second $\left(\mathrm{FEV}_{1}\right),{ }^{5}$ the forced vital capacity (FVC) ${ }^{5}$ the $\mathrm{FEV}_{1} / \mathrm{FVC}$ ratio, ${ }^{6}$ and the total lung capacity (TLC) ${ }^{7}$ are shown. A single breath diffusing capacity (DCO) ${ }^{8}$ adjusted for haemoglobi and the alveolar volume $\left(\mathrm{V}_{\mathrm{A}}\right)$ are also given. The arterial blood gases on room air were $\mathrm{pH} 7 \cdot 41, \mathrm{pCQ}$ : 42 , and $\mathrm{pO}_{2}$ 87. A lung compliance study indicated the static compliance ${ }^{9}$ was decreased at $0.112 \mathrm{l} / \mathrm{cm} \mathrm{H}_{2} \mathrm{R}$ and that the elastic recoil pressure ${ }^{10}$ was increased $44.4 \mathrm{~cm} \mathrm{H} \mathrm{H}_{2} \mathrm{O}$ (measured at $55 \%$ predicted TLC).

The following were normal or negative: electrolyte glucose, BUN, creatinine, liver enzymes, packed c\$ volume, haemoglobin, white cell count, urine analysi antinuclear antibodies, and rheumatoid factor. Results of sputum analyses for acid fast organisms an 

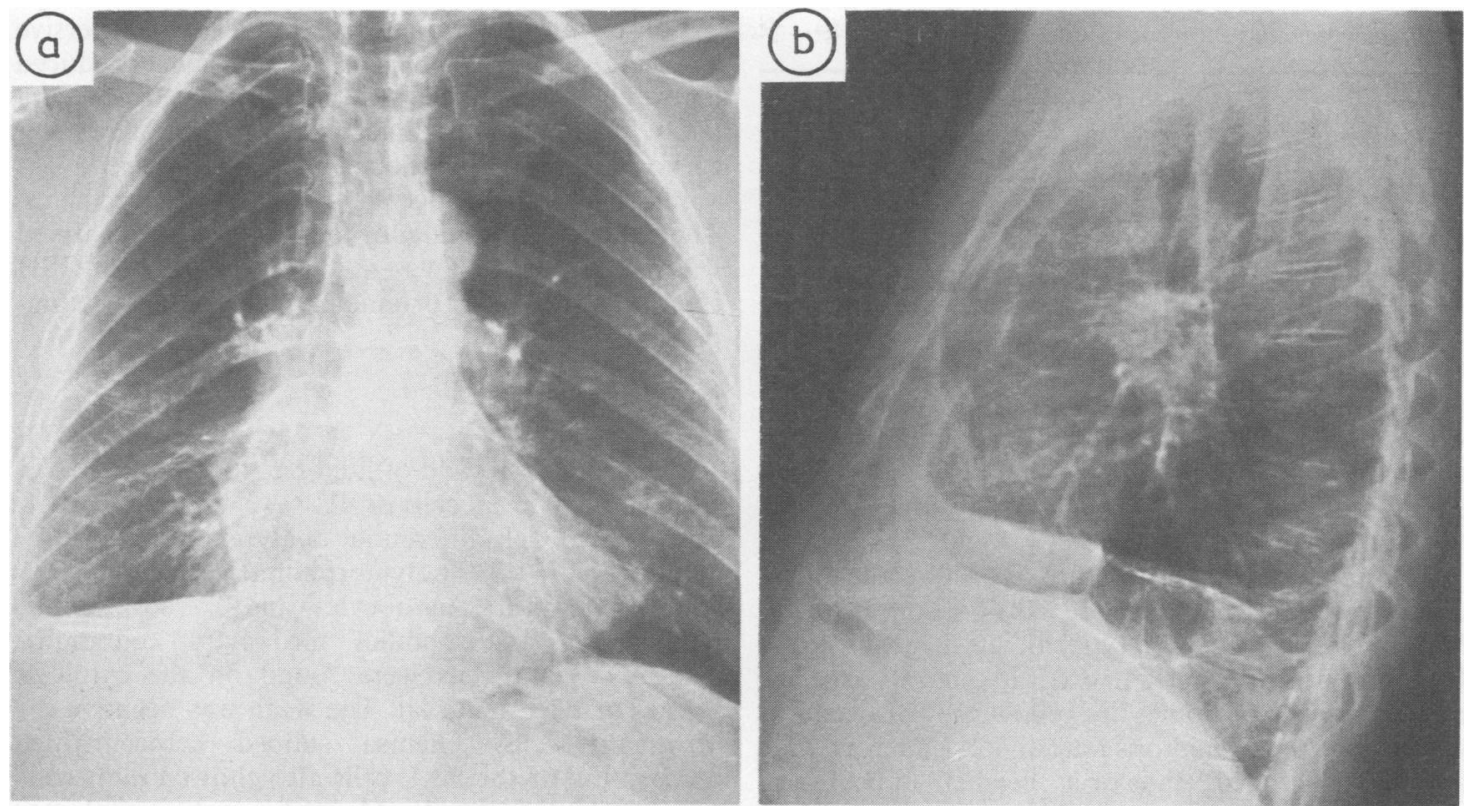

Fig 1 (A) \& (B) 1986 chest radiographs showing bilateral pleural thickening, calcification on both hemidiaphragms, and pleuropericardial adhesions.

and neoplasia were negative. Asbestos bodies were not evident on the sputum cytology examination. The patient would only consent to bronchoscopy as an aide to elucidate the diagnosis.

\section{Methods and materials}

Bronchoscopy was performed with a TR model flexi- ble fibreoptic bronchoscope (Olympus Corporation of America, New Hyde Park, NY). One right middle lobe segment was lavaged with $150 \mathrm{ml}$ of physiological saline in $50 \mathrm{ml}$ aliquots after which transbronchial lung biopsies were performed.

The BAL fluid retrieved was prepared for analysis by a standard protocol. " Briefly, it was pooled and spun at $250 \mathrm{Xg}$ for 10 minutes. The cell pellets were

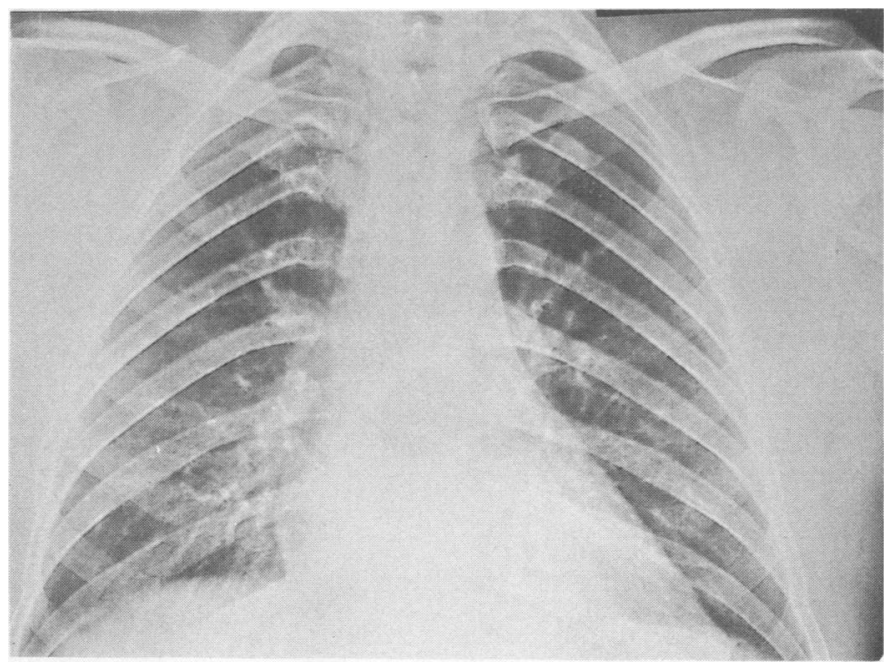

Fig 21970 chest radiograph showing pleural plaque in right mid-lung region. 
Pulmonary function

\begin{tabular}{|c|c|c|}
\hline & Observed & $\%$ of Predicted \\
\hline 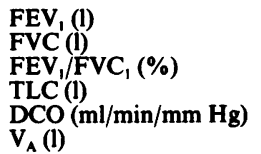 & $\begin{array}{c}1 \cdot 91 \\
2 \cdot 49 \\
77 \\
3 \cdot 24 \\
17 \cdot 5 \\
3 \cdot 28\end{array}$ & $\begin{array}{l}61 \\
58 \\
54 \\
65 \\
54\end{array}$ \\
\hline
\end{tabular}

combined and resuspended in RPMI 1640 (Gibco, Grand Island, NY). Several cytocentrifuge slide preparations were made (spun at $22.4 \mathrm{Xg}$ ) and stained with Giemsa. The cell differential count was then determined by examination of 300 cells. A total cell count from a fixed BAL aliquot was determined microscopically with a haemocytometer.

The remaining cell mixture was filtered on to cellulose membrane (Millipore Corporation, Bedford, MA; porosity, $0.45 \mu \mathrm{m})$. Hypochlorite digestion of the BAL cells was performed in order to quantify asbestos bodies. ${ }^{12}$ Asbestos bodies are yellow brown structures measuring 20-150 microns long and 2-5 microns wide and have "clubbed" ends or a "beaded" appearance, or both. ${ }^{13}$ After air drying, the filters were mounted on glass slides and the slides studied with an optical microscope. A manual count of the entire filter for asbestos bodies was performed. Lavage material was also sent to the UCLA Medical Center clinical cytology laboratory for processing. The transbronchial lung biopsies were processed by the clinical pathology laboratory.
For scanning electron microscopy-energy dispersive $\overline{\bar{a}}$ $x$ ray analysis (SEM-EDXA), ${ }^{14}$ the cell pellet produced 3 on the glass slide in the cytocentrifuge was treated as a $\stackrel{\mathbb{P}}{?}$ tissue section and transferred from the slide to $\mathrm{a} \underset{\Rightarrow}{\Rightarrow}$ carbon disc using acrylic medium. This procedure is $\stackrel{?}{\rightarrow}$ applicable to any cytocentrifuge prepared specimens. The particles (fibrous and non-fibrous) are analysed $\frac{\bar{\sigma}}{\overline{2}}$ within the macrophages in the specimen. ${ }^{15}$ NIOSH standards (75-0043 for amosite) were used for com- $\stackrel{\mathbb{\nabla}}{\AA}$ parison. ${ }^{14}$

\section{Results}

There was a $67 \%$ yield of fluid return from the BAL, $\stackrel{\sigma}{\circ}$ with $41 \times 10^{6}$ total cells or $41 \times 10^{4}$ cells $/ \mathrm{ml}$ of BAL fluid return. Cell differential analysis indicated $84 \%$ macrophages, $1.8 \%$ polymorphonuclear cells, $13.2 \%$ के lymphocytes, $1.0 \%$ monocytes, and $0 \%$ eosinophils. î Numerous asbestos bodies, histiocytes, and multi- $\vec{\nabla}$ nucleated giant cells were found on the cytology

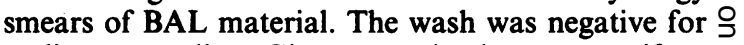
malignant cells. Giemsa stained cytocentrifuge preparation of the BAL cells also showed numerous asbestos bodies (fig 3). Manual counting of hypochlorite digestion of BAL specimens identified about 13.4 asbestos bodies per $\mathrm{ml}$ of BAL fluid volume or 26.4 asbestos bodies per $1 \times 10^{6}$ BAL cells. The $\overrightarrow{0}$ transbronchial lung biopsy specimens were non-dia\& nostic. An asbestos body was found in one sma specimen and an area of minimal fibrogenesis was noted in another biopsy specimen.

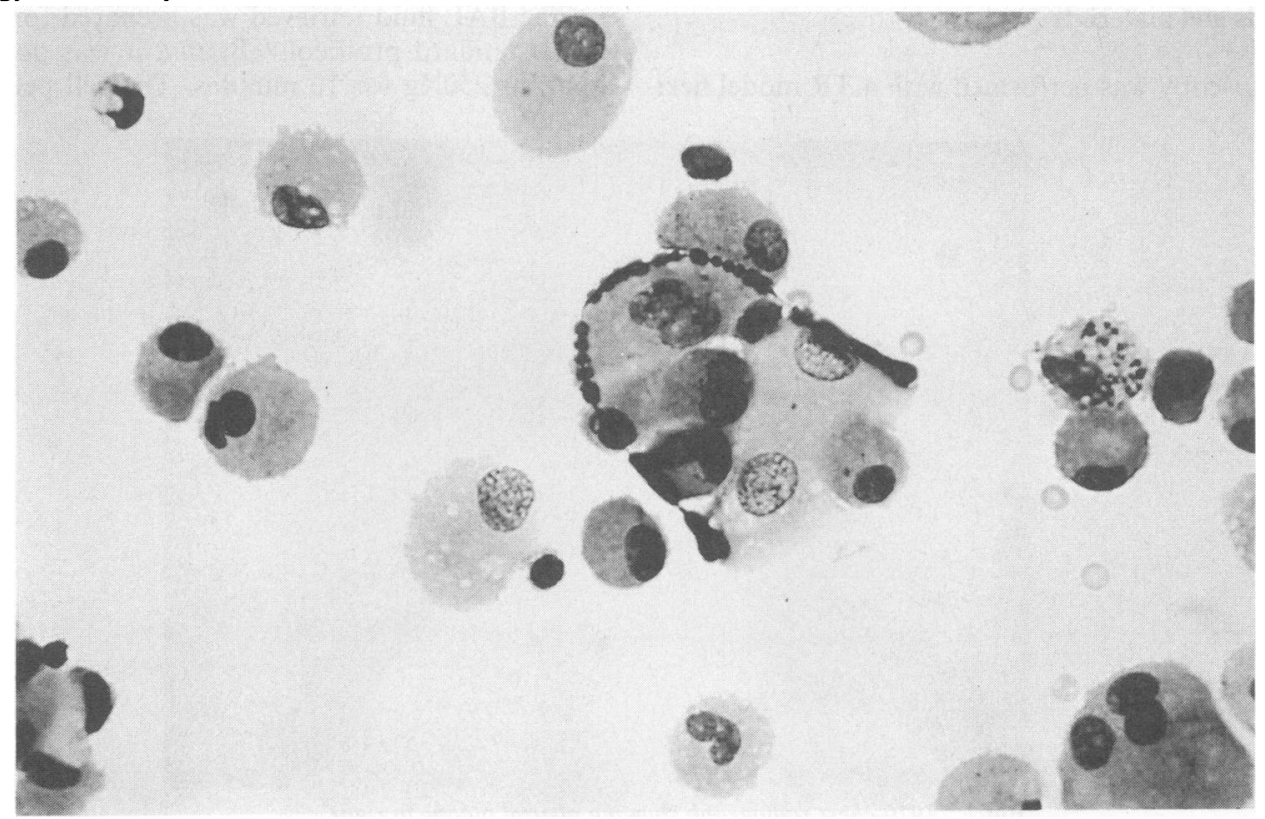

Fig 3 Giemsa stain of BAL specimen showing curved asbestos body. 

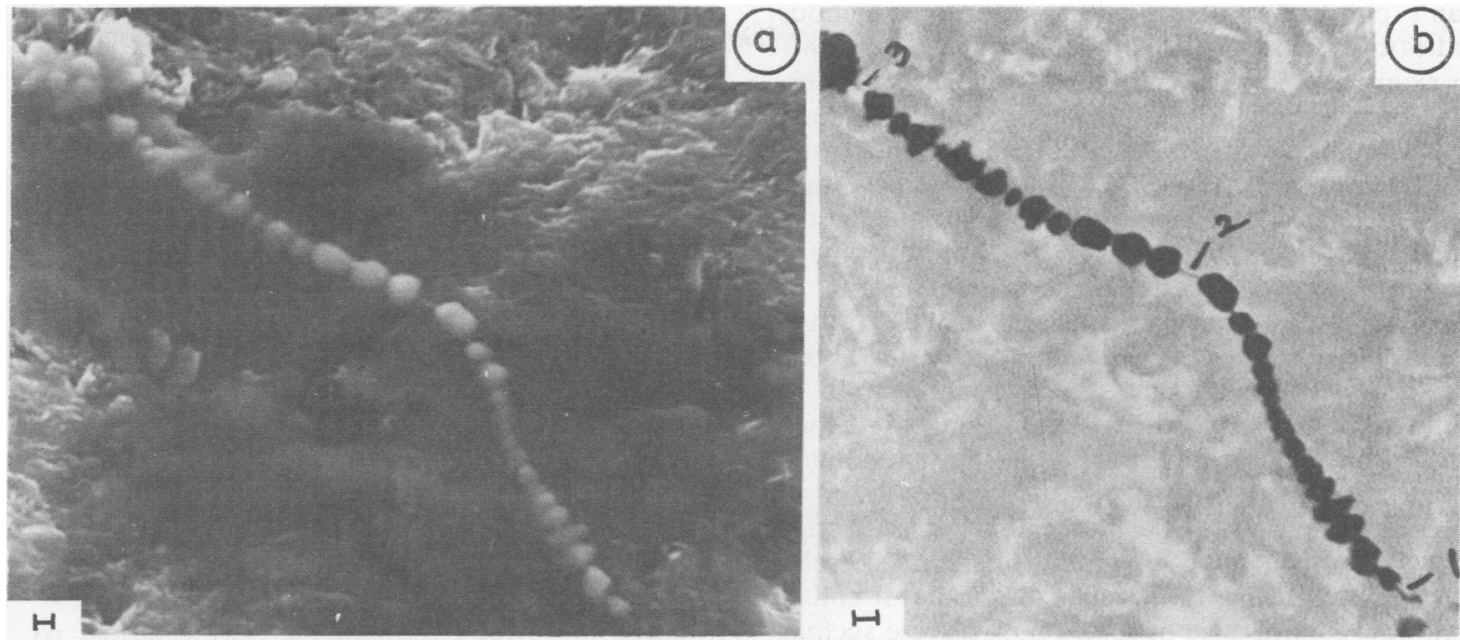

Fig 4 Scanning electron microscope images of an asbestos body within an alveolar macrophage obtained by lavage. Magnification marker represents 1.0 micrometer. (A) Secondary electron image shows dark outline of macrophage.

(B) Backscattered electron image of asbestos body within alveolar macrophage. Energy dispersive $x$ ray analysis was done on areas marked.

The SEM-EDXA analysis of the BAL specimens showed numerous inorganic particulates. The fibre core of the asbestos bodies (fig 4) was shown by EDXA to be consistent with amosite.

\section{Discussion}

Although the clinical assessment of the pathological response to exposure to asbestos is available, attributing the abnormalities directly to such exposure may often be difficult. The assessment of asbestos related lung disease may be difficult because the patient may be unaware of the risks of exposure to asbestos or may be uncertain of the exposure. The periods of exposure, the amount of exposure, or the types of fibres inhaled may also be unknown to the patient. Furthermore, because of the long latent period, asbestos related pulmonary abnormalities may appear to occur "suddenly" in a previously healthy individual.

One index of exposure that has been advocated is the finding of asbestos bodies in lung specimens. ${ }^{16-18}$ Sputum analysis for asbestos bodies is not very sensitive. ${ }^{19}$ Biopsy procedures such as transbronchial lung biopsies, percutaneous needle lung biopsies, and open lung biopsies are fraught with risks and, except in the last, the samples obtained may be too small to make an adequate analysis. One technique that has recently come into clinical use to evaluate other types of pulmonary diseases is BAL. ${ }^{20}$ BAL has recently been found to be a useful adjunct to confirm asbestos exposure, ${ }^{21} 22$ although it does not yield a direct tissue diagnosis.

The SEM-EDXA analysis of BAL cells allows examination for inorganic particulates. In addition, asbestos bodies and fibres can be identified and quantified. ${ }^{23} 24$

Although asbestos related lung diseases-for example, mesotheliomas-may occur after a brief or low dose exposure, this case illustrates the occurrence of another asbestos related lung disease - that is, asbestosis-after a brief known exposure period. The BAL cell differential analysis was within the normal limits as defined by prior BAL controls." The transbronchial lung biopsies were not revealing and considered nondiagnostic, but the surprising find of numerous asbestos bodies in the BAL specimens substantiated the exposure. De Vuyst et al performed a quantitative analysis of BAL specimens and recently reported that more than half the subjects who had definite asbestos exposure and more than one third of the subjects with probable exposure had from 1 to 99 asbestos bodies per ml of BAL specimen. ${ }^{21}{ }^{22}$ More than three quarters of the subjects with a clinical diagnosis of asbestosis and only one third of those with pleural disease reported by De Vuyst et al had greater than 10 asbestos bodies per $\mathrm{ml}$ of BAL specimen. Although our patient's history suggested that he had only a small cumulative asbestos exposure, the BAL specimen clearly showed a raised lung burden of asbestos which strengthened the diagnosis of asbestosis. The extensive pleural changes also suggested that he may have had significant exposure to asbestos. Many cases of radiographically detected bilateral pleural thickening are thought to be due to exposure to asbestos often undetected by routine history. ${ }^{25}$ The presence of interstitial disease radiologically (and restrictive disease physiologically) also led to the diagnosis of asbestosis as the best possible explanation for this 
man's pulmonary abnormalities. Since ferruginous bodies may be associated with other inhaled silicatesfor example, talc ${ }^{13}$ - a SEM-EDXA analysis was performed to confirm the presence of asbestos fibres, most of which were amosite. The predominance of amosite fibres detected by SEM-EDXA was also substantiating information for exposure. Amphibole asbestos such as amosite has been a major asbestos fibre type in commercially used asbestos in the United States. ${ }^{26}$

We have shown another clinical use for BAL. It is helpful in substantiating exposure to asbestos fibres. Analysis of the BAL such as the quantification of asbestos bodies and SEM-EDXA analysis helped confirm the exposure. Recent studies have attempted to associate the number of asbestos bodies found in BAL with the severity of asbestos lung disease. ${ }^{16-18} \mathrm{De}$ Vuyst and others have shown that there is a correlation between the number of asbestos bodies found in BAL and the presence of severe lung disease such as asbestosis in individuals at risk for asbestos related lung diseases. ${ }^{2122}$

In conclusion, we have found BAL a useful means of detecting asbestos exposure when the exposure history is in doubt. Although it may be an extreme example of biological monitoring, BAL has been shown to have a clinically useful role in a variety of diseases-for example, idiopathic pulmonary fibrosis (IPF) or sarcoidosis. ${ }^{20}$ This present case illustrates that in many cases of IPF BAL may also be useful to substantiate the presence of asbestos fibres or other inorganic substances, or both, when lung biopsy analysis, as in our case, is unavailable or inadequate. We emphasise that the findings of BAL do not make the diagnosis of asbestosis, which is established on the basis of exposure history, clinical, radiological, and physiological data (and by histopathology, when available), and by the exclusion of other possible aetiologies for restrictive lung disease.

We thank Dr Philip Harber (Department of Medicine, Pulmonary Division) for reviewing the manuscript and Ms Nancy Marshello and Ms Bonnie Cazeault for preparing the manuscript. " $B$ " reading of $x$ rays was done by Dr Philip Harber.

Requests for reprints to: Richard G Barbers, MD, Department of Medicine, University of Massachusetts Medical School, 55 Lake Avenue, North, Worcester, MA 01655.

\section{References}

1 Becklake MR. Asbestos-related diseases of the lung and other organs - their epidemiology and implications for clinical practice. Am Rev Respir Dis 1976;114:187-227.

2 Utidjian MD, Gross P, de Treville R. Ferruginous bodies in human lungs. Arch Environ Health 1968;17:327-33.

3 Churg A, Warnock ML. Asbestos fibers in the general population. Am Rev Respir Dis 1980;122:669-78.

4 International Labour Office. Guidelines for the use of ILO inter- national classification of radiographs of pneumoconiosis. Rev ed $\overline{\bar{z}}$ Geneva: International Labour Office, 1980. (Occupationa safety and health series No 22.)

5 Detels R, Tashkin DP, Simmons MS, et al. The UCLA population studies of chronic obstructive respiratory disease. 5. Agreement; and disagreement of tests in identifying abnormal lung function Chest 1982;82:630-8.

6 Goldman HI, Becklake MR. Respiratory function tests. Norma? values at median altitudes and the prediction of normal results American Review of Tuberculosis 1959;79:457-67.

7 Cotes JE. Lung function. Assessment and application in medicine Oxford: Blackwell, 1979.

8 Dinakara P, Blumenthal WS, Johnston RF, Kauffman LA ֶ Solnick PB. The effect of anemia on pulmonary diffusing capacity with derivation of a correction equation (note). $\operatorname{Am} \operatorname{Re}$ Respir Dis 1970;102:956-9.

9 Schlueter DP, Immekus J, Stead WW. Relationship between $\vec{\omega}$ maximal inspiratory pressure and total lung capacity (coefficient of retraction) in normal subjects and in patients witl居 emphysema, asthma and diffuse pulmonary infiltration. $\mathrm{Am} \operatorname{Re} \mathrm{S}$ Respir Dis 1967;96:656-65.

10 Turner JM, Mead J, Wohl ME. Elasticity of human lungs in relation to age. $J$ Appl Physiol 1968;25:664-71.

11 Barbers RG, Gong H, Tashkin DP, Oishi J, Wallace JM $\overrightarrow{0}$ Differential examination of bronchoalveolar lavage (BAL) cells in cigarette tobacco and marijuana smokers. Am Rev Respio Dis 1987;135:1271-5.

12 Williams MG, Dodson RF, Corn C, Hurst GA. A procedure for $\overrightarrow{-}$ the isolation of amosite asbestos and ferruginous bodies from lung tissue and sputum. J Toxicol Environ Health 1982;10, 627-38.

13 Craighead JE, Abraham JL, Churg A, et al. The pathology of asbestos associated diseases of the lungs and pleural cavities. Diagnostic criteria and proposed grading schema. Arch Patholo Lab Med 1982;106:544-96.

14 Abraham JL, Burnett BR. Quantitative analysis of inorgangic particulate burden in situ tissue sections. Scanning Electon Microscopy 1983;2:681-96.

15 Mason GR, Abraham JL, Hoffman L, Cole S, Lippman Wasserman K. Treatment of mixed-dust pneumoconiosis with whole lung lavage. Am Rev Respir Dis 1982;126:1102-7.

16 Churg A, Wiggs B, Depaoli L, Kampe D, Stevens B. Lung asbesto content in chrysotile workers with mesothelioma. Am Rev Respir Dis 1984;130:1042-5.

17 Churg A. Asbestos fiber content of the lungs in patients with and without asbestos airways disease. Am Rev Respir Di. 1983;127:470-3.

18 Roggli BL, Pratt PC. Numbers of asbestos bodies on iron stained. tissue sections in relation to asbestos body counts in lung tissue digest. Hum Pathol 1983;14:355-61.

19 Roggli VL, Greenberg SD, McLarty JW, et al. Comparison of sputum and lung asbestos body counts in former asbestos workers. Am Rev Respir Dis 1980;122:941-5.

20 Hunninghake GW, Gadek JE, Kawanami O, Ferras VJ, Crystaß RG. Inflammatory and immune processes in the human lung in health and disease. Evaluation by bronchoalveolar lavage. $A m b$ Pathol 1979;97:149-206.

21 De Vuyst P, Jedwab J, Dumortier P, Vandermoten G, Weyer RVP Yernault JC. Asbestos bodies in bronchoalveolar lavage. An Rev Respir Dis 1982;126:972-6.

22 De Vuyst P, Dumortier P, Monlin E, Yourassowsky N, Yernaul JC. Diagnostic value of asbestos bodies in bronchoalveola lavage fluid. Am Rev Respir Dis 1987;136:1219-24.

23 Rubin ID, Maggiore CJ. Elemental analysis of asbestos fibers b. means of electron probe techniques. Environ Health Perspectr 1974;9:81-94.

24 Langer AM, Mackler AD, Pooley FD. Electron microscopicáf investigation of asbestos fibers. Environ Health Perspec 1974;9:63-80.

25 Abelda SM, Epstein DM, Gefter WB. Pleural thickening: its significance and relationship to asbestos dust exposure. Am Reg Respir Dis 1982;128:621-4.

26 Hueper WC. Occupational and non-occupational exposure tø asbestos. Ann NY Acad Sci 1965;132:184-95. 